Alicja Klamczyńska

Ministerstwo Sprawiedliwości ${ }^{1}$

Tomasz Ostropolski

Ministerstwo Sprawiedliwości ${ }^{2}$

\title{
PRAWO DO ADWOKATA W DYREKTYWIE 2013/48/UE - TŁO EUROPEJSKIE I IMPLIKACJE DLA POLSKIEGO USTAWODAWCY
}

\section{Wprowadzenie}

Jednym z kluczowych ogniw Przestrzeni Wolności, Bezpieczeństwa i Sprawiedliwości w UE jest współpraca wymiarów sprawiedliwości UE w sprawach karnych. Instrumenty przyjmowane $\mathrm{w}$ jej ramach dawały podstawy do coraz szerszej kooperacji, koncentrując się jednak, w pierwszych latach jej funkcjonowania, na represyjnym wymiarze oraz interesie organów wymiaru sprawiedliwości ${ }^{3}$ Taki jej profil był wyrazem określonej roli tej dziedziny wśród unijnych polityk. Początkowo bowiem instrumenty prawa karnego miały pełnić rolę ,środków kompensacyjnych” (mesures compensatoires), których zasadniczym celem było zaradzenie negatywnym skutkom swobody przepływu osób. Nie dziwi zatem, że zasadniczy nacisk kładziono na usprawnienie mechanizmów współpracy służących zwalczaniu transgranicznej przestępczości.

Niezależnie od przyczyn o charakterze politycznym, na drodze rozwojowi instrumentarium prawnego o charakterze gwarancyjnym stały względy prawne, tj. brak bezpośredniej podstawy traktatowej dla przyjmowania środków legislacyjnych w tym zakresie ${ }^{4}$. Co prawda, już w 2001 r. przyjęto decyzję ramową regulującą kwe-

1 Alicja Klamczyńska jest głównym specjalistą w Wydziale Europejskiego Prawa Karnego w Ministerstwie Sprawiedliwości. W niniejszym artykule autorzy przedstawiają jedynie własne poglądy.

2 Dr Tomasz Ostropolski jest naczelnikiem Wydziału Europejskiego Prawa Karnego w Ministerstwie Sprawiedliwości. W niniejszym artykule autorzy przedstawiają jedynie własne poglądy.

3 Zob. też A. Grzelak, T. Ostropolski, Współpraca wymiarów sprawiedliwości w sprawach karnych i współpraca policyjna (wyd. 2), Warszawa 2011, s. 134.

$4 \quad$ W Traktacie o Unii Europejskiej w kolejnych wersjach (z Maastricht, z Amsterdamu i z Nicei), w art. 31 ust. 1 nie wymieniano „praw procesowych” jako jednego z działań objętych współpracą. Możliwość działań legislacyjnych w tym zakresie wywodzono jednak z otwartego charakteru katalogu wskazanego w tym artykule. 
stie z obszaru prawa procesowego (decyzja ramowa Rady 2001/220/WSiSW z dnia 15 marca 2001 r. w sprawie pozycji ofiar w postępowaniu karnym ${ }^{5}$ ), tym niemniej przez długi czas odmawiano nadania jej roli precedensu, który mógłby legitymizować dalsze działania służące ochronie praw procesowych.

Przez kolejne lata kwestia ochrony praw jednostek była zatem regulowana $\mathrm{w}$ instrumentach prawa karnego co najwyżej pośrednio. $\mathrm{Np}$. w art. 11 ust. 1 decyzji ramowej Rady 2002/584/WSiSW z 13 czerwca 2002 r. w sprawie europejskiego nakazu aresztowania i procedury wydawania osób między państwami członkowskimi ${ }^{6}$ (dalej jako: DR ENA) stwierdza się, że „osoba, której dotyczy wniosek, aresztowana w celach wykonania ENA, ma prawo do korzystania z pomocy prawnej i z pomocy thumacza zgodnie z prawem krajowym wykonującego nakaz państwa członkowskiego". Nie wydaje się jednak, aby deklaracja ta kreowała roszczenia po stronie jednostki. W szczególności naruszenie tego typu uprawnienia nie stanowi przesłanki odmowy wykonania ENA wymienionej w art. 3-4a DR ENA. W ówczesnych realiach poprzestawano bowiem zwykle na konstatacji, że odpowiedni korpus praw procesowych jest zapewniony w każdym państwie członkowskim, choćby z tytułu bycia stroną Europejskiej Konwencji Praw Człowieka ${ }^{7}$. Miało się to łączyć ze wzajemnym zaufaniem do systemów prawnych (i pośrednio kwestionować potrzebę zbliżania standardów gwarancyjnych w UE).

Niemniej jednak stopniowo dochodzono do przekonania, że takie podejście byłoby niewystarczające. Skłoniło to do podjęcia działań w celu zniwelowania istniejącej nierównowagi pomiędzy środkami represyjnymi a korpusem gwarancyjnym. W 2004 r. Komisja przedłożyła projekt decyzji ramowej Rady w sprawie niektórych praw proceduralnych $w$ postępowaniu karnym ${ }^{8}$. Jej celem było zapewnienie w całej UE (wybranych) minimalnych gwarancji procesowych określonych w jednym instrumencie prawnym (prawa do obrony, do informacji o istotnych uprawnieniach, pomocy tłumacza, pomocy konsularnej oraz pomocy dla osób szczególnie narażonych) dla podejrzanych i oskarżonych. Projekt nie został jednak finalnie przyjęty ze względu na sprzeciw kilku państw członkowskich, które zarzucały mu naruszenie zasady proporcjonalności oraz wspomniany wyżej brak podstaw traktatowych dla ingerencji w wewnętrzną procedurę karną. Wskazywano również na zbędność działania UE w tej sferze w sytuacji, kiedy wszystkie państwa członkowskie są związane $\mathrm{EKPCZ}^{9}$.

Stawało się jednak jasne, że dalszy rozwój współpracy wymiarów sprawiedliwości UE w sprawach karnych nie jest możliwy przy pominięciu sfery ochrony praw

5 Dz.U. UE z 22.3.2001 r., L 82/1.

6 Dz.U. UE z 18.7.2002 r., L 190/1.

7 Nie omawiamy tutaj szerzej kwestii dopuszczalności odmowy wykonania ENA ze względu na naruszenie praw podstawowych.

$8 \quad$ KOM (2004) 328 wersja ostateczna.

9 Zob. Council Press release 10267/07. https://www.consilium.europa.eu/ueDocs/cms_Data/docs/pressData/en/ jha/94682.pdf 
jednostek. Tymczasowo przyjmowano środki fragmentarycznie odnoszące się do tej kwestii, np. poprzez rozbudowę i uszczegółowienie przesłanek odmowy uznania i wykonania orzeczenia w sytuacji, kiedy postępowanie w państwie wydającym było prowadzone in absentia ${ }^{10}$.

Sytuacja ta miała się radykalnie zmienić dopiero w obliczu wejścia w życie Traktatu z Lizbony ${ }^{11}$, który znosił problem podstawy prawnej. Art. 82 ust. 2 lit. b TFUE wprowadzał bowiem możliwość ustanawiania norm minimalnych dotyczących praw jednostek w postepowaniu karnym. W związku z tym, podjęto dyskusje nad możliwym sposobem dalszego zaangażowania Unii w tej dziedzinie. Podkreślano, że całościowa regulacja w przedmiocie praw procesowych powinna stanowić bodziec do wzrostu wzajemnego zaufania, a tym samym - do skuteczniejszej realizacji zasady wzajemnego uznawania stanowiącej podstawę współpracy wymiarów sprawiedliwości UE w sprawach karnych.

W obliczu braku powodzenia przyjęcia pojedynczego aktu prawnego (wspomnianej wyżej decyzji ramowej) oraz w perspektywie ,lizbońskich” podstaw prawnych, przyjęto odmienną koncepcję opracowywania kolejnych aktów prawnych, które miały się odnosić do poszczególnych praw w postępowaniu karnym. Uznano, że takie podejście „krok po kroku” pozwoli uniknąć powtórzenia poprzednich doświadczeń i przyczyni się do sprawniejszego przebiegu negocjacji.

W efekcie tych dyskusji w dniu 30 listopada 2009 r. Rada przyjęła rezolucję określającą „Harmonogram działań mających na celu umocnienie praw procesowych osób podejrzanych lub oskarżonych w postępowaniu karnym"12. W harmonogramie tym (,mapie drogowej”) zawarto szereg działań dotyczących uregulowania praw, którym powinien zostać nadany priorytet. Zastrzeżono jednak, że możliwe jest ich uzupełnienie. Wymieniono tam 5 środków, które powinny stać się przedmiotem inicjatyw legislacyjnych oraz wskazano na jedną dziedzinę do dalszej refleksji w ramach zielonej księgi. Do środków tych należą:

- Środek A: tłumaczenia pisemne i ustne,

- Środek B: informowanie o prawach i informowanie o zarzutach,

- Środek C: porada prawna i pomoc prawna,

- Środek D: kontakt z krewnymi, pracodawcami i organami konsularnymi,

- Środek E: specjalne zabezpieczenia dla osób podejrzanych lub oskarżonych wymagających szczególnego traktowania,

- Środek F: Zielona księga w sprawie tymczasowego aresztowania.

\footnotetext{
10 Zob. decyzja ramowa Rady 2009/299/WSiSW z dnia 26 lutego 2009 r. zmieniająca decyzje ramowe 2002/584/ WSiSW, 2005/214/WSiSW, 2006/783/WSiSW, 2008/909/WSiSW oraz 2008/947/WSiSW i tym samym wzmacniająca prawa procesowe osób oraz ułatwiająca stosowanie zasady wzajemnego uznawania do orzeczeń wydanych pod nieobecność danej osoby na rozprawie, Dz. Urz. UE z 27.3.2009 r., L 81/24.

11 Dz.U. UE z 30.3.2010 r., C 83/1.

12 Dz.U. UE z 4.12.2009 r., C 295/1.
} 
W Programie Sztokholmskim ${ }^{13}$ Rada Europejska potwierdziła, że ochrona praw podejrzanych i oskarżonych $\mathrm{w}$ postępowaniu karnym stanowi jedną z podstawowych wartości Unii, mającą duże znaczenie dla utrzymania wzajemnego zaufania, oraz uznała, że przyjęty harmonogram stanowi część Programu.

Pierwszymi instrumentami przyjętymi w drodze jego realizacji była Dyrektywa Parlamentu Europejskiego i Rady 2010/64/UE z dnia 20 października 2010 r. $\mathrm{w}$ sprawie prawa do thumaczenia ustnego i thumaczenia pisemnego w postępowaniu karnym ${ }^{14}$ oraz dyrektywa Parlamentu Europejskiego i Rady 2012/13/UE z dnia 22 maja 2012 r. w sprawie prawa do informacji w postępowaniu karnym ${ }^{15}$. Nie ulegało jednak wątpliwości, że najbardziej ambitnym i najtrudniejszym instrumentem z całego harmonogramu będzie środek $\mathrm{C}$ dotyczący „porady prawnej i pomocy prawnej” (legal advice and legal aid).

W obliczu złożoności materii, różnic pomiędzy prawodawstwem państw członkowskich oraz antycypowanych trudności negocjacyjnych, Komisja zdecydowała się podzielić zapowiadany przedmiot środka $\mathrm{C}$ i wyodrębnić kwestie prawa dostępu do adwokata (right of access to a lawyer) oraz pomocy prawnej (legal aid). W czerwcu 2011 r. Komisja przedstawiła projekt dyrektywy dotyczący tej pierwszej kwestii ${ }^{16}$. Równocześnie włączono do niego regulacje, które w ramach harmonogramu zapowiadano jako środek $\mathrm{D}$, tj. kontakt $\mathrm{z}$ krewnymi, pracodawcami i organami konsularnymi.

Regulacje projektu oparły się w dużym stopniu na orzecznictwie ETPCz, w szczególności na wyroku z dnia 27.11.2008 r. w sprawie Salduz ${ }^{17}$. W pewnym zakresie Komisja wychodziła jednak ponad standardy strasburskie, proponując dalej idące gwarancje dostępu do adwokata. Projekt zawierał następujące założenia:

- zapewnienie dostępu do adwokata od pierwszego etapu przesłuchania policyjnego, od momentu pozbawienia wolności oraz przez cały czas trwania postępowania karnego;

- umożliwienie osobie podejrzanej i oskarżonej poufnych spotkań z adwokatem;

- przyznanie adwokatowi prawa do kontroli warunków zatrzymania;

- zapewnienie osobie podejrzanej możliwości poinformowania co najmniej jednego członka rodziny lub pracodawcy o swoim zatrzymaniu;

- zezwolenie osobie podejrzanej lub oskarżonej pozbawionych wolności za granicą na poinformowanie ambasady lub konsulatu o ich pozbawieniu wolności oraz na skontaktowanie się z tymi placówkami;

Dz.U. UE z 4.5.2010 r., C 115/1.

Dz.U. UE z 26.10.2010 r., L 280/1.

Dz.U. UE z 1.6.2012 r., L 142/1.

$\operatorname{KOM}(2011) 326$ wersja ostateczna.

Salduz przeciwko Turcji, wyrok z 27.11.2008 r., skarga nr 36391/02. 
- zapewnienie osobom objętym ENA możliwości zasięgnięcia porady prawnej zarówno w kraju, w którym dokonano aresztowania, jak i w kraju, w którym nakaz wydano;

- zasadniczy zakaz korzystania z dowodów uzyskanych w warunkach odmowy dostępu do adwokata.

\section{Problemy negocjacyjne}

W toku negocjacji nad projektem dyrektywy ujawniło się szereg problemów, nieraz o zasadniczym charakterze. Po części wypływały one z różnic pomiędzy systemami prawnymi państw członkowskich. Dodatkowym wyzwaniem była dynamika orzecznictwa ETPCz w tym zakresie. Kilka lat wcześniej doszło mianowicie do przełomowego orzeczenia Trybunału w sprawie Salduz ${ }^{18}$, w którym podkreślono, że prawo do rzetelnego procesu obejmuje konieczność zapewnienia prawa dostępu do adwokata już na wczesnym etapie postępowania przygotowawczego (przesłuchanie przez policję), gdyż złożone wówczas zeznania mogą zaważyć na wyniku postępowania. Skutki tego orzeczenia powodowały również implikacje finansowe w niektórych państwach.

W tym kontekście jednym z podstawowych wyzwań było rozumienie pojęcia „dostępu do adwokata” przez poszczególne państwa. Jak miało się okazać, rozdzielenie materii „prawa do dostępu do adwokata” oraz ,pomocy prawnej” na 2 projekty dyrektyw nie rozwiązało całkowicie problemu. W niektórych państwach prawo dostępu do adwokata jest równoznaczne $\mathrm{z}$ jego (choćby tymczasowym) zapewnieniem przez organy procesowe w sytuacji, kiedy osoba ta nie posiada (jeszcze) własnego obrońcy (tzw. guarantee approach). Koszty tej obrony mogą być następnie rozliczone na końcu postępowania. Z kolei inne państwa rozumieją prawo dostępu do adwokata jako sposobność zaoferowaną uczestnikowi postępowania, z której może (bądź nie) skorzystać (tzw. opportunity approach). Ta grupa państw ściśle oddziela kwestię prawa dostępu do adwokata (z którego skorzystanie ma charakter potencjalny, zależny od podjęcia inicjatywy przez samą osobę zainteresowaną) od pomocy prawnej (jako „gwarancji” uzyskania dostępu), która jest uznawana za całkowicie odrębną instytucję.

Kolejnym problemem było określenie momentu, od którego prawo dostępu do adwokata znajduje zastosowanie. O ile orzeczenie Salduz pokazało dobitnie, że prawo to przysługuje już na wczesnym etapie postępowania przygotowawczego, to w dalszym ciągu nie była jasna korelacja pomiędzy uzyskaniem statusu podejrzanego a możliwością korzystania z tego prawa. Sam zresztą moment uzyskania określonego statusu procesowego różnił się w prawodawstwach poszczególnych państw, odmienny mógł być również sposób powiadomienia danej osoby o jej roli proceso- 
wej, które miałoby aktualizować przedmiotowe prawo. Kwestią związaną z zakresem obowiązywania dyrektywy było również określenie wyjątków odnoszących się do tzw. drobnych przestępstw. Dotyczyło to w szczególności wykroczeń drogowych.

Część negocjacji była poświęcona dostępowi do adwokata w trakcie niektórych czynności dowodowych, które część państw całkowicie kwestionowała. Jedną z propozycji, która jednak nie zyskała uznania delegatów, było wprowadzenie rozwiązania zbliżonego do obowiązującego w art. 316 par. 1 k.p.k., tj. uzależnienia dopuszczenia adwokata do udziału w czynności od jej niepowtarzalnego charakteru oraz niebezpieczeństwa utraty lub zniekształcenia dowodu w razie zwłoki. Większość wyraziła wszelako preferencję dla wskazania wprost czynności, przy których prawo dostępu do adwokata znajdzie zastosowanie.

Jedną z najbardziej spornych kwestii były derogacje od prawa dostępu do adwokata. W pierwotnym projekcie Komisji zostały one określone bardzo wąsko; było zatem jasne, że tak restryktywne podejście się nie ostanie. Powstało również pytanie, czy zakres derogacji powinien być jednolity, czy też zróżnicowany w stosunku do każdego aspektu prawa dostępu do adwokata (gromadzenie dowodów, poufność, powiadomienie osoby trzeciej, ENA). Najwięcej kontrowersji wzbudziła możliwość odstępstwa od prawa do poufności w kontaktach z adwokatem. O ile powszechnie zgadzano się, że poufność jest immanentnym elementem prawa dostępu do adwokata i nie może być ograniczona w ten sam sposób jak inne jego aspekty, to spierano się co do tego, czy derogacje powinny być w tym przypadku w ogóle (nawet w wąskiej formule) dopuszczalne. Jak się miało później okazać, kwestia ta była granicą kompromisu dla Parlamentu Europejskiego, który kładł nacisk na konieczność absolutnego charakteru tego prawa.

Pierwotny projekt Komisji zdeterminował również kierunek dyskusji nad kwestią zrzeczenia się prawa dostępu do adwokata. Projektodawca (opierając się częściowo na orzecznictwie ETPCz), przyjął mianowicie założenie, iż sam fakt niewykonywania uprawnienia nie może świadczyć w dorozumiany sposób o tym, że strona nie zamierza z niego korzystać, lecz konieczne jest złożenie wyraźnego oświadczenia, którego warunki miały być uzgodnione w dyrektywie.

Nowatorskim elementem dyrektywy było zapewnienie prawa dostępu do adwokata $\mathrm{w}$ toku procedury ENA, mając na uwadze, że aspekt ten nie jest objęty art. 6 $\mathrm{EKPCZ}^{19}$. Komisja dążyła do zapewnienia tego prawa zarówno w państwie wydającym, jak i wykonującym ENA, gdy tymczasem wiekszość państw członkowskich kwestionowała taką zasadność w państwie wydającym. Wskazywano na niejasną rolę, jaką miałby odgrywać adwokat w tym państwie oraz fakt, że osoba ścigana i tak będzie miała możliwość obrony w prowadzonym tamże postępowaniu głównym, po jej przekazaniu. 
Wreszcie, sporo kontrowersji wzbudziła kwestia konsekwencji naruszenia prawa dostępu do adwokata. W projekcie Komisji proponowano zasadniczy zakaz korzystania z dowodów uzyskanych w warunkach odmowy dostępu do adwokata, z wyjątkiem nadzwyczajnych okoliczności, w których wykorzystanie takich dowodów nie naruszy prawa do obrony. Tak dogmatyczne podejście było nie do zaakceptowania dla części państw członkowskich (w szczególności skandynawskich), w których nie ustanawia się ścisłych reguł dowodowych oraz nie zakreśla precyzyjnie skutków ich naruszenia, pozostawiając bardzo szeroki zakres uznania sędziowskiego.

Istniała również praktycznie jednomyślność państw członkowskich - wbrew stanowisku Komisji - co do braku zasadności obejmowania prawem do adwokata możliwości kontroli warunków zatrzymania osoby.

Powyższe kwestie były stosunkowo długo debatowane w Radzie. Porozumienie pomiędzy państwami członkowskimi nie zamykało jednak dyskusji, gdyż na ostatecznie przyjętym tekście w kilku aspektach wyraźne piętno odcisnął współprawodawca, tj. Parlament Europejski.

Ostatecznie po 2 latach trudnych negocjacji dyrektywa 2013/48/UE Parlamentu Europejskiego i Rady o prawie dostępu do adwokata w postępowaniu karnym i w ramach procedury europejskiego nakazu aresztowania oraz o prawie do poinformowania osoby trzeciej o pozbawieniu wolności, a także do komunikowania się z osobami trzecimi i władzami konsularnymi osób pozbawionych wolności, została przyjęta w dniu 22 października 2013 r. ${ }^{20}$

\section{Zawartość dyrektywy}

\section{Zakres przedmiotowy i podmiotowy}

Dyrektywa reguluje prawo dostępu do adwokata oraz poufność kontaktów $\mathrm{z}$ adwokatem (art. 3 i 4), prawo do poinformowania osoby trzeciej o pozbawieniu wolności oraz komunikowania się z osobami trzecimi w przypadku pozbawienia wolności (art. 5 i 6), prawo do komunikowania się z organami konsularnymi (art. 7), ogólne warunki czasowych odstępstw (art. 8), uprawnienie zrzeczenia się praw (art. 9), prawo dostępu do adwokata w ramach ENA (art. 10), pomoc prawną z urzędu (art. 11) oraz środki w przypadku naruszenia praw (art. 12). W porównaniu do projektu Komisji Europejskiej uchwalona dyrektywa nie obejmuje prawa adwokata do kontroli warunków zatrzymania. Wśród środków przysługujących w przypadku naruszenia prawa nie uwzględniono również proponowanego przez Komisję zakazu dowodowego. 
Dyrektywa ma zastosowanie do postępowania karnego (z wyjątkami wskazanymi w motywie 13. preambuły ${ }^{21}$ ) oraz procedury wykonania ENA. Termin ,postępowanie karne” stosowany na gruncie dyrektywy obejmuje także „drobne przestępstwa”. Jednakże w przypadku, gdy za „drobne przestępstwo” możliwe jest nałożenie sankcji przez organ inny niż sąd właściwy w sprawach karnych, do którego istnieje jednak droga odwoławcza (art. 2 ust. 4 lit. a) lub nie ma możliwości orzeczenia za nie kary pozbawienia wolności (art. 2 ust. 4 lit. b), prawa przyznane w dyrektywie stosuje się jedynie na etapie postępowania przed sądem. Motywy 16. i 17. preambuły wymieniają przykładowo ,drobne przestępstwa”, w odniesieniu do których stosowanie praw z dyrektywy uzasadnione jest jedynie na etapie postępowania przed sądem ${ }^{22}$.

Podmiotowy zakres dyrektywy wyznacza art. 2 ust. 1-3. Stosuje się ją do podejrzanych i oskarżonych od momentu, gdy zostali poinformowani w formie oficjalnego zawiadomienia lub w inny sposób, że są podejrzewani lub oskarżeni o popełnienie przestępstwa. Ponadto dyrektywa ma zastosowanie także do osób, które w trakcie przesłuchania uzyskały status podejrzanych lub oskarżonych ${ }^{23}$ oraz do osób poszukiwanych na podstawie ENA od momentu ich zatrzymania.

Wątpliwości może wzbudzać odniesienie do innego sposobu powiadomienia o podejrzeniu popełnienia przestępstwa, warunkującego przyznanie praw na mocy dyrektywy. Wyjaśnienia w tym względzie dostarczać może orzecznictwo ETPCz ${ }^{24}$. Wskazuje ono, że „oskarżenie” oznacza oficjalne powiadomienie o zarzutach, ale również istotną zmianę sytuacji procesowej danej osoby, co może mieć miejsce $\mathrm{w}$ momencie jej zatrzymania lub wszczęcia postępowania przeciwko tej osobie ${ }^{25}$. Tym samym prawa przewidziane w dyrektywie powinny mieć zastosowanie nie tylko w sytuacji postawienia osobie zarzutu, ale również w przypadku podjęcia wobec niej innych czynności, które mogą wskazywać na fakt, iż jest ona podejrzewana o popełnienie czynu.

\section{Moment powstania i zakres prawa do adwokata}

Moment, od którego aktualizuje się prawo dostępu do adwokata, wyznaczany jest z jednej strony uzyskaniem statusu podejrzanego lub oskarżonego (art. 2 ust. 1

Wyjątki dotyczą drobnych przestępstw popełnianych w więzieniu lub w kontekście służby wojskowej, którymi zajmuje się dowódca.

22 Np. przypadki mniejszej wagi popełniane na szeroką skalę i stwierdzane w wyniku kontroli drogowej, polegające na naruszeniu przepisów władz lokalnych czy też związane z naruszeniem porządku publicznego.

23 Zob. motyw 21. preambuły. Dyrektywa przewiduje ochronę dla świadków, którzy w trakcie przesłuchania uzyskują status podejrzanych lub oskarżonych.

24 Wyrok ETPCz z 18.02.2010 r. w sprawie Zaichenko przeciwko Rosji, skarga nr 39660/02, wyrok z 5.01.1982 r. w sprawie Eckle przeciwko Niemcom, skarga nr 8130/78.

25 Wskazać należy, iż wyrok dotyczy pojęcia „oskarżenie”, do którego odnosi się art. 6 EKPCz. Tymczasem prawa określone w dyrektywie wykraczają zakresowo poza art. 6 EKPCz (dotyczą też: powiadomienia osoby trzeciej, komunikowania się z organami konsularnymi w przypadku pozbawienia wolności, procedury ENA). W związku z tym jak się wydaje, należy zakładać, że zgodnie z dyrektywą zarówno prawo dostępu do adwokata (objęte 6 EKPCZ), jak i pozostałe prawa z dyrektywy aktywują się nie tylko w momencie postawienia osobie zarzutu, ale podjęcia wobec niej innych czynności wskazujących na fakt podejrzenia. 
dyrektywy), z drugiej - przeprowadzeniem czynności przez właściwe organy (art. 3 ust. 2 w zw. z art. 2 ust. 1 dyrektywy). Czynności, o których dyrektywa wspomina, to przesłuchanie przez policję $\mathrm{i}$ inne organy postępowania, zatrzymanie i tymczasowe aresztowanie, okazanie, odtworzenie przebiegu zdarzenia i konfrontacja, a także wezwanie do stawiennictwa przed sądem. Podjęcie przez organ którejkolwiek z tych czynności jako pierwszej powoduje powstanie prawa dostępu do adwokata ${ }^{26}$.

Zakres prawa dostępu do adwokata określa z kolei art. 3 ust. 3 dyrektywy. Przepis wskazuje, że prawo to obejmuje prawo do spotkania z nim na osobności i komunikowania się, prawo do ,skutecznego” udziału adwokata w przesłuchaniu, a także w trakcie okazania, konfrontacji oraz odtworzenia przebiegu zdarzenia.

Posługując się terminem, ,prawo dostępu do adwokata” oraz wprowadzając możliwość zrzeczenia się tego prawa (art. 9), dyrektywa nie wprowadza obowiązku spotkania i komunikowania się z adwokatem (art. 3 ust. 3 lit. a), ani też jego obowiązkowej obecności w trakcie wskazanych czynności (art. 3 ust. 3 lit. b i c), lecz uzależnia je od woli podejrzanego (i oskarżonego). Jeśli ten nie zrzeka się swojego prawa, właściwe organy powinny umożliwić nawiązanie kontaktu z adwokatem (zgodnie z art. 3 ust. 4) oraz jego udział w tych czynnościach. Wyjaśniają to szerzej motywy 27. i 28. dyrektywy. Rozróżnia się tam (nie do końca klarownie) charakter obowiązków państw w zależności od tego, czy podejrzany lub oskarżony przebywa na wolności. Wobec przebywających na wolności państwa powinny „dokładać starań", aby ułatwić im dostęp do adwokata, np. poprzez upowszechnienie informacji o prawie, o danych kontaktowych adwokatów. Expressis verbis wskazuje się jednak, że nie należy wymagać od państw członkowskich aktywnego zapewniania, aby podejrzani lub oskarżeni, którzy nie zostali pozbawieni wolności, korzystali z pomocy adwokata, jeżeli sami nie zapewnili sobie takiej pomocy. W odniesieniu do pozbawionych wolności podejrzanych lub oskarżonych obowiązki te określone są nieco inaczej. Przede wszystkim kładzie się nacisk na „skuteczne” skorzystanie $\mathrm{z}$ prawa dostępu do adwokata przez pozbawionych wolności (art. 3 ust. $4^{27}$ ). W tym względzie w motywie 28. przewiduje się wprowadzenie niezbędnych rozwiązań, aby zapewnić takim osobom możliwość skutecznego korzystania z prawa dostępu do adwokata, w tym zorganizować pomoc adwokata, jeśli osoby te nie posiadają

26 ETPCz zwracał szczególną uwagę na konieczność zapewnienia adwokata na wczesnym etapie postępowania (przesłuchanie przez policję - Salduz przeciwko Turcji, wyrok z 27.11.2008 r., skarga nr 36391/02; Pishchalnikov przeciwko Rosji, wyrok z 24.09.2009 r., skarga nr 7025/04; Brusco przeciwko Francji, wyrok z 14.10.2010 r., skarga nr 1466/07; zatrzymanie lub tymczasowe aresztowanie - wyrok w sprawie Adamkiewicz przeciwko Polsce z 02.03.2010 r., skarga nr 54729/00; okazanie - Mehmet Şerif Öner przeciwko Turcji, wyrok z 13.09.2011 r., skarga nr 50356/08; odtworzenie przebiegu zdarzenia - Shabelnik przeciwko Ukrainie, wyrok z 19.02.2009 r., skarga $\mathrm{nr}$ 16404/03).

27 ETPCz często podkreślał, że prawa przyznane w EKPCz powinny być rzeczywiste i skuteczne, nie zaś teoretyczne (zob. wyrok z 27.11.2008 r., w sprawie Salduz przeciwko Turcji, skarga nr 36391/02, wyrok z 13.01.2009 r., w sprawie Rybacki przeciwko Polsce, skarga nr 52479/99). Część państw członkowskich w trakcie negocjacji wskazywała, że o skuteczności świadczy wyłącznie faktyczne zapewnienie obecności adwokata w sytuacji, gdy zainteresowany sam go nie ustanowił. Pozostała część twierdziła jednak, że równałoby się to de facto pomocy prawnej, która nie jest przedmiotem dyrektywy ani wymogiem EKPCz. 
adwokata i jeśli nie zrzekły się tego prawa. Przykładowo wskazuje się, że właściwe organy organizują pomoc adwokata na podstawie wykazu dostępnych adwokatów, spośród których podejrzany lub oskarżony mógłby dokonać wyboru. Zaznacza się również, że takie rozwiązania mogłyby w stosownych przypadkach obejmować rozwiązania dotyczące pomocy prawnej z urzędu (pamiętać jednak należy o art. 11, który zastrzega, że dyrektywa pozostaje bez uszczerbku dla prawa krajowego dotyczącego pomocy z urzędu).

Co do zasady, organy powinny umożliwić podejrzanym i oskarżonym skorzystanie z prawa do adwokata. Jedynie w wyjątkowych przypadkach organy mogą odmówić kontaktu z adwokatem lub przeprowadzenia czynności w jego obecności, tj. jeśli podyktowane jest to pilną potrzebą zapobieżenia zagrożeniu dla życia, zdrowia i wolności człowieka, a także istotnemu uszczerbkowi dla postępowania karnego (art. 3 ust. 6 dyrektywy) ${ }^{28}$. W przypadku zaistnienia wspomnianych zagrożeń, zgodnie z motywami 31. i 32. preambuły można, co prawda, przesłuchać osobę bez obecności adwokata, jeśli zapewni się jej odpowiednie gwarancje, jednak przesłuchanie to powinno być ograniczone do uzyskania niezbędnych informacji mogących zapobiec powstaniu określonych skutków dla życia lub zdrowia, lub dla materiału dowodowego. W sytuacji zatem, gdy policja lub prokurator chcieliby przesłuchać osobę na okoliczności popełnienia czynu w zakresie wykraczającym poza uzyskanie informacji koniecznych do zabezpieczenia dowodów i ochrony osób, a osoba nie zrzekła się swojego prawa do adwokata, przesłuchanie takie powinno odbyć się z jego udziałem.

Czasowe odstępstwa od prawa dostępu do adwokata określone w art. 3 ust. 6 powinny podlegać ogólnym rygorom odstępstw przewidzianym w art. 8 dyrektywy dotyczącym proporcjonalności, ograniczenia w czasie, braku uzależnienia ich stosowania od rodzaju lub wagi przestępstwa, nienaruszalności rzetelnego procesu, stosowania i kontroli przez właściwe organy.

\section{Prawo do adwokata w trybie ENA}

Dyrektywa przewiduje prawo do adwokata zarówno w państwie wydania, jak i wykonania ENA. O ile jednak określa ona sposób wykonywania prawa do adwokata w państwie wykonania ENA, o tyle nie czyni tego w przypadku państwa wydania ENA. Zdecydowano się na pozostawienie w tym zakresie swobody państwom członkowskim jako kompromisowego rozwiązania w świetle podnoszonych przez nie wątpliwości odnośnie celowości, skuteczności i kosztów związanych z realizacją prawa dostępu do adwokata w państwie wydania ENA w związku z jego wykonaniem. Uzgodniono jedynie, że osoba poszukiwana na podstawie ENA będzie

28 W tym zakresie dyrektywa przewiduje dalej idącą ochronę podejrzanych/oskarżonych niż wynikająca z orzecznictwa ETPCz. W licznych wyrokach Trybunał formułował ograniczenia praw w sposób bardziej ogólny posługując się terminem compelling reasons bez wskazywania konkretnych przyczyn: Salduz przeciwko Turcji, wyrok z wyrok z 27.11.2008 r., skarga nr 36391/02, Brennan przeciwko Wielkiej Brytanii, wyrok z 16.10.2001 r., skarga $\mathrm{nr} 39846 / 98)$. 
mieć prawo do wyznaczenia adwokata w państwie wydania na podstawie informacji przekazanych jej w tym celu przez organ państwa wydania ENA (art. 10 ust. 5 dyrektywy). Celem wyznaczenia adwokata w państwie wydania jest zapewnienie pomocy adwokatowi w państwie wykonania (art. 10 ust. 4). Pomoc taka może ostatecznie przyczynić się do odstąpienia od wykonania ENA (osoba dobrowolnie stawi się przed organami w państwie wydania ENA), a w konsekwencji do oszczędności kosztów.

Prawo dostępu do adwokata w państwie wykonania ENA różni się nieco od przyznanego w toku zwykłego postępowania karnego. Wynika to z odmiennych celów obydwu postępowań. W przeciwieństwie bowiem do zwykłego postępowania w trakcie ENA nie ustala się odpowiedzialności osoby ściganej i nie przeprowadza w tym celu czynności dowodowych (tj. okazanie, konfrontacja czy odtworzenie przebiegu zdarzenia), ergo nie przewiduje się udziału adwokata w takich czynnościach. Prawo do adwokata w państwie wykonania ENA przysługuje z momentem zatrzymania osoby objętej ENA i obejmuje uprawnienie do poufnych spotkań i komunikowania się z adwokatem oraz do obecności adwokata $\mathrm{w}$ trakcie przesłuchania przez sąd (art. 10 ust. 2).

\section{Poufność kontaktów $z$ adwokatem}

Dyrektywa w art. 4 wprowadza bezwzględną poufność kontaktów z adwokatem w każdej formie: spotkań, korespondencji, rozmów telefonicznych oraz innych form dopuszczalnych na gruncie krajowym. Przepis ten nie przewiduje żadnych ograniczeń tej zasady. W motywach 33. i 34. preambuły dyrektywa definiuje jednocześnie pewne działania, które należy uznać za dopuszczalne i nie naruszające tej zasady ${ }^{29}$. Zachowań tych nie można jednakże utożsamiać z odstępstwami od poufnych kontaktów $\mathrm{z}$ adwokatem. Zasada ta powinna być stosowana tak w ramach postępowania karnego, jak i w trybie ENA (art. 10 ust. 3).

\section{Skutki naruszenia prawa do adwokata}

Jak wspomniano wyżej, pierwotny projekt Komisji przewidywał m.in. zakaz powoływania się przez sąd na wyjaśnienia podejrzanego oraz na dowody pozyskane z naruszeniem prawa do adwokata lub przy zastosowaniu wyłączeń od tego prawa. Dyrektywa, uwzględniając różnice w systemach państw członkowskich, nie statuuje takiego zakazu. Zobowiązuje natomiast państwa do tego, by w takich przypadkach zapewniały przestrzeganie prawa do obrony i rzetelnego procesu (art. 12 ust. 2). Nie

Motywy 33. i 34. wskazują, że zasada poufnych kontaktów nie doznaje uszczerbku w przypadku stosowania procedur krajowych w sytuacji uzasadnionego podejrzenia zaangażowania adwokata w popełniony przez podejrzanego (lub oskarżonego) czyn. Dozwolone są również procedury stosowane wobec osób pozbawionych wolności, mające na celu zapewnienie bezpieczeństwa w zakładach karnych i aresztach śledczych, polegające na przeglądaniu korespondencji, jednak w sposób, który prowadzi jedynie do ujawnienia np. niebezpiecznych przedmiotów, nie zaś treści komunikatów między obrońcą i podejrzanym lub oskarżonym. Ponadto w zgodzie z dyrektywą pozostają działania stosowane przez służby odpowiedzialne za zapewnienie bezpieczeństwa państwa i porządku publicznego zgodnie $z$ art. 4 ust. 2 Traktatu o UE lub art. 72 Traktatu o Funkcjonowaniu UE. 
wskazuje przy tym sposobu na osiągnięcie tego celu. Takie rozwiązanie pozwala na uwzględnienie stosowanej w szeregu państw członkowskich zasady swobodnej oceny dowodów przez sąd.

\section{Implementacja dyrektywy w prawie polskim}

W ostatnim czasie w polskiej procedurze karnej miały miejsce istotne zmiany w zakresie dostępu do obrońcy. Wiązało się to z wprowadzonym tzw. dużą nowelizacją kodeksu postępowania karnego ${ }^{30}$ modelem procesu kontradyktoryjnego. Jego konsekwencją było rozszerzenie instytucji obrony z urzędu poprzez możliwość przyznania jej bez badania sytuacji finansowej oskarżonego ${ }^{31}$. W naturalny sposób zmiany te dotyczyły wyłącznie postępowania sądowego, dla którego właściwy jest model kontradyktoryjny rodzący z kolei konieczność zapewnienia równości broni. Tym samym wprowadzona nowela k.p.k. nie dotykała obszarów najbardziej relewantnych z punktu widzenia dyrektywy, a zatem momentu, od którego powstaje prawo dostępu do adwokata, a także jego faktycznego zakresu, w świetle akcentowanego w dyrektywie wymogu ,skuteczności”.

\section{Zakres przedmiotowy}

Jak wskazano wyżej, prawa przewidziane w dyrektywie będą miały zastosowanie również w przypadku popełnienia „drobnych przestępstw”. Sposób, w jaki dyrektywa odwołuje się do „drobnych przestępstw” (art. 2 ust. 4 dyrektywy, motyw 16. i 17. preambuły ${ }^{32}$ ), wskazuje na konieczność stosowania jej - na gruncie prawa polskiego - również w odniesieniu do wykroczeń. W praktyce oznacza to więc, że ocenę potrzeby zmian w prawie polskim w zakresie dotyczącym gwarancji proceduralnych należałoby dokonywać w świetle obowiązujących przepisów zarówno kodeksu postępowania karnego, jak i kodeksu postępowania w sprawach o wykroczenia.

Z uwagi na przewidziane w art. 2 ust. 4 dyrektywy wyłączenia dyrektywa powinna być stosowana bądź to wyłącznie na etapie postępowania przed sądem (w przypadku wykroczeń, za które policja lub inny uprawiony organ może nałożyć grzywnę w drodze mandatu karnego - art. 2 ust. 4 lit. a) lub za które nie grozi kara aresztu - art. 2 ust. 4 lit. b), bądź też również w toku czynności wyjaśniających (w pozostałych przypadkach wykroczeń).

Tymczasem zgodnie z obowiązującymi przepisami k.p.w. prawo do obrońcy albo adwokata ${ }^{33}$ przysługuje odpowiednio przed sądem (art. 4 w zw. z art. $20 \S 1$

30 Ustawa z dnia 27 września 2013 r.
ustaw (Dz.U. z 2013 r., poz. 1247).

Zob. w szczególności art. 80a k.p.k.

Zob. pkt 3.1. Zakres przedmiotowy i podmiotowy.

K.p.k. posługuje się zarówno terminem „adwokat”, jak i „obrońca”. Rozróżnienie to jest konsekwencją wyodrębnienia w tym postępowaniu podejrzanego (art. $71 \S 1$, art. $73 \S 1$ k.p.k.) i osoby podejrzanej (np. art. $74 \S 3$, art. $245 \S 1$ k.p.k.). Podobnie jest na gruncie kodeksu postępowania w sprawach o wykroczenia (dalej: k.p.w.) prze- 
k.p.w.) oraz w przypadku zatrzymania (art. $46 \S 4$ k.p.w.). Przepisy k.p.w. nie przewidują prawa do obrońcy (prawo do adwokata) na etapie czynności wyjaśniających. Postrzegając brak regulacji w zakresie prawa do obrońcy na tym etapie jako potencjalnie niezgodny z Konstytucją RP i EKPCz, Rzecznik Praw Obywatelskich złożył wniosek do Trybunału Konstytucyjnego ${ }^{34}$. Wniosek nie został dotychczas rozpoznany. Niezależnie jednak od wyników postępowania przed Trybunałem, w związku $\mathrm{z}$ implementacją dyrektywy konieczne wydaje się przewidzenie w k.p.w. prawa dostępu do adwokata również na etapie czynności wyjaśniających, w zakresie nieobjętym wspomnianymi wyłączeniami $z$ art. 2 ust. 4 dyrektywy.

\section{Zakres podmiotowy}

Jak wskazano wyżej, dyrektywa ma zastosowanie zarówno wobec osób, którym postawiono zarzut, jak też podjęto czynności wskazujące na fakt podejrzenia ich o popełnienie czynu. Na gruncie prawa polskiego, prawa określone w dyrektywie powinny mieć $\mathrm{w}$ związku $\mathrm{z}$ tym zastosowanie nie tylko do podejrzanego, wobec którego wydano postanowienie o przedstawieniu zarzutów lub bez wydania takiego postanowienia przesłuchano $\mathrm{w}$ charakterze podejrzanego (art. $71 \S 1$, art. 308, art. 325 g k.p.k.), czy do oskarżonego (art. $71 \S 2$ k.p.k.), ale również do osoby podejrzanej, której nie został przedstawiony jeszcze zarzut, jednak przeprowadza się z jej udziałem czynności $\mathrm{w}$ celu potwierdzenia przypuszczeń co do popełnienia przez nią czynu, bądź też wykluczenia jej z kręgu potencjalnych sprawców (art. 74 § 3 k.p.k.). Ponadto $\mathrm{z}$ uwagi na fakt, iż dyrektywę stosować się będzie również do wykroczeń, z praw przewidzianych w dyrektywie korzystać powinna: osoba, wobec której prowadzone są czynności wyjaśniające i która w ich trakcie może zostać poddana określonym czynnościom (art. $54 \S 5$ k.p.w.) oraz która może być przesłuchana po powiadomieniu jej o zarzutach (art. $54 \S 6$ k.p.w.) - w zakresie nieobjętym wyjątkami z art. 2 ust. 4 dyrektywy, a także obwiniony, wobec którego wystąpiono do sądu z wnioskiem o ukaranie (art. 20 § 1 k.p.w.).

Przyznanie osobie podejrzanej praw wynikających z dyrektywy znajduje uzasadnienie w orzecznictwie Trybunału Konstytucyjnego ${ }^{35}$, który podzielając pogląd Sądu Najwyższego ${ }^{36}$ stwierdził, że ,nie formalne postawienie zarzutu popełnienia przestępstwa, lecz już pierwsza czynność organów procesowych skierowana na ściganie określonej osoby czyni ją podmiotem prawa do obrony". W tym kontekście nasuwa się pytanie o sposób implementacji prawa dostępu do adwokata w prawie polskim. Komisja Kodyfikacyjna Prawa Karnego (KKPK) opowiada się za zrówna-

widuje zarówno prawo do adwokata (art. $46 \S 4$ k.p.w.), jak i prawo do obrońcy (art. 4 k.p.w., art. 20 k.p.w.). Pod pojęciem prawa do adwokata w rozumieniu dyrektywy należy zatem na gruncie prawa polskiego przyjmować zarówno prawo do adwokata, jak i prawo do obrońcy.

34 Wniosek RPO w sprawie K 19/11, dostępny na stronie: http://otk.trybunal.gov.pl/orzeczenia/ezd/sprawa_lista_plikow.asp?syg=K\%2019/11

35 Wyrok TK z 11.12.2012 r., K 37/11, OTK-A 2012, nr 11, poz. 133.

36 Wyrok SN z 9.02.2004 r., sygn. V KK 194/03, OSNKW nr 4/2004, poz. 42, uchwała SN z 26.04.2007 r., sygn. I KZP 4/07, OSNKW nr 6/2007, poz. 45. 
niem statusu tych osób wskazując, że zarówno podejrzany, jak i osoba podejrzana powinny $w$ równym stopniu korzystać z prawa do obrony ${ }^{37}$. Alternatywnym rozwiązaniem mogłoby być rozszerzenie uprawnień osoby podejrzanej bez rezygnacji z jej odrębnego statusu.

\section{Przesłuchanie i inne czynności dowodowe}

Jak zostało wskazane wyżej, z dyrektywy wynika, że organy krajowe powinny ułatwić kontakt $\mathrm{z}$ adwokatem, w tym w przypadku pozbawienia wolności ${ }^{38}$, lub jego udział w czynnościach, w których uczestniczy podejrzany lub oskarżony. Nie są natomiast zobowiązane do zapewnienia obowiązkowej obecności adwokata w trakcie czynności przeprowadzanych z udziałem podejrzanego lub oskarżonego ${ }^{39}$. W tym świetle pozytywnie należy ocenić zmianę wprowadzoną do k.p.k., mającą na celu ułatwienie kontaktu z obrońcą z urzędu ${ }^{40}$.

Co prawda, dyrektywa nie wskazuje za pomocą jakich środków państwa powinny ułatwić udział adwokata w czynnościach przesłuchania, okazania, odtworzenia przebiegu zdarzenia czy konfrontacji, niemniej jednak wydaje się, iż jeśli prawo do adwokata miałoby być wykonywane w sposób „skuteczny”, to dla organów krajowych powinno to oznaczać możliwość: a) odroczenia czynności w celu wyznaczenia adwokata, by mógł on wziąć w niej udział (o ile nie zachodzą okoliczności uzasadniające zastosowanie czasowych wyłączeń z art. 3 ust. 6 dyrektywy ${ }^{41}$ ), b) powiadomienia adwokata o miejscu i terminie czynności, c) odroczenia czynności w przypadku niestawiennictwa adwokata przynajmniej wówczas, gdy jego obecność jest obowiązkowa lub gdy usprawiedliwił swoje niestawiennictwo i wniósł o odroczenie, d) umożliwienia udziału obrońcy w czynności, nawet jeśli poprzednio została ona przeprowadzona $\mathrm{z}$ jego udziałem.

Mając na uwadze powyższe wymogi, w celu zapewnienie zgodności prawa polskiego z dyrektywą, w szczególności w aspekcie skuteczności, konieczne będzie wprowadzenie zmian dotyczących przede wszystkim:

a) przesłuchania podejrzanego z udziałem obrońcy (art. 301 k.p.k. ${ }^{42}$ ). Przepis ten nie jest jednolicie stosowany. Niemniej jednak w świetle przeważającego

37 Zob. opinię KKPK na temat implementacji dyrektywy 2013/48/UE. Opinie KKPK dostępne są na stronie: http:// bip.ms.gov.pl/pl/dzialalnosc/komisje-kodyfikacyjne/komisja-kodyfikacyjna-prawa-karnego/opinie-komisji -kodyfikacyjnej-prawa-karnego/

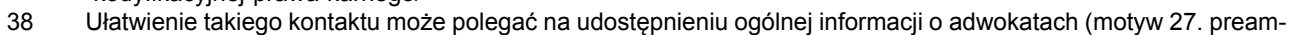
buły) lub na innych działaniach, $\mathrm{np}$. skontaktowaniu się z adwokatem wybranym przez podejrzanego z przedstawionej mu listy adwokatów (motyw 28. preambuły).

39 Pojęcie „podejrzany i oskarżony” stosowane jest w dalszej części tego punktu jedynie dla uproszczenia. W przypadku regulacji krajowych pod tym pojęciem należy bowiem rozumieć również pozostałe kategorie osób, wobec których stosuje się prawo do adwokata.

40 Zob. art. 81a k.p.k. wprowadzony ustawą z dnia 27 września 2013 r. o zmianie ustawy - Kodeks postępowania karnego oraz innych ustaw (Dz.U. z 2013 r., poz. 1247). Przepis upoważnia Ministra Sprawiedliwości m.in. do określenia sposobu ustalania listy obrońców udzielających pomocy prawnej z urzędu, sposobu kontaktu z obrońcą w sprawach pilnych.

41 Można przesłuchać osobę bez obecności adwokata, jeśli istnieje poważne zagrożenie dla życia lub zdrowia, bądź konieczność zabezpieczenia dowodów przed istotnym uszczerbkiem.

42 Przepis ten ma zastosowanie również do przesłuchania osoby podejrzanej, o której mowa w art. 325 g k.p.k. 
stanowiska doktryny z przepisu tego wynikają następujące reguły ${ }^{43}$ : a) obowiązek umożliwienia udziału obrońcy w przesłuchaniu dotyczy jedynie ustanowionego już obrońcy, b) brak obowiązku odroczenia przesłuchania w celu umożliwienia podejrzanemu ustanowienia obrońcy, c) w przypadku przesłuchania podejrzanego bez obrońcy, może on żądać, by przesłuchano go ponownie w obecności ustanowionego obrońcy, d) prawo do przesłuchania z udziałem obrońcy przysługuje wyłącznie raz, e) niestawiennictwo obrońcy nie tamuje przesłuchania. Wobec powyższego przepis ten może wymagać stworzenia możliwości odroczenia przesłuchania, gdy podejrzany nie ma ustanowionego obrońcy, jak również, gdy obrońca nie stawił się, zaś powiadomiony o przesłuchaniu wniósł o jego odroczenie;

b) przesłuchania osoby, wobec której prowadzone są czynności wyjaśniające (art. 54 § 6 k.p.w.) w zakresie nieobjętym wyłączeniami z art. 2 ust. 4 dyrektywy. Przepis art. $54 \S 6$ k.p.w. nie przewiduje udziału adwokata w przesłuchaniu, podczas gdy - jak wskazano wyżej - prawo do adwokata powinno przysługiwać również na etapie czynności wyjaśniających;

c) okazania podejrzanego, osoby podejrzanej (art. $74 \S 3$ k.p.k.) oraz obwinionego (art. $20 \S 3$ k.p.w.). Okazanie uważane jest za czynność niepowtarzalną. Zgodnie $\mathrm{z}$ art. $316 \S 1$ k.p.k. dotyczącym czynności, których nie można powtórzyć na rozprawie, obrońcę podejrzanego (tylko jednak, jeśli jest w sprawie ustanowiony) należy wezwać do udziału w takiej czynności, o ile nie zachodzi obawa utraty bądź zniekształcenia dowodów. Przepis ten nie przewiduje jednak udziału adwokata osoby podejrzanej w czynności jej okazania. Brak też odpowiednika art. 316 w k.p.w. Przepis art. 316 k.p.k. powinien ulec zmianie tak, by umożliwić podejrzanemu ustanowienie obrońcy przed czynnością okazania, jak również udział w okazaniu adwokata osoby podejrzanej. Zmiany w podobnym kierunku wymagałyby również przepisy k.p.w. w odniesieniu do obwinionego;

d) odtworzenia przebiegu zdarzenia z udziałem podejrzanego i osoby podejrzanej. Jest to czynność, która może mieć niekiedy charakter niepowtarzalny. W innych przypadkach należałoby ją traktować jako inną czynność w rozumieniu art. 317 k.p.k. Zgodnie z tym przepisem obrońca podejrzanego może wziąć udział w czynności, jeśli jednak został ustanowiony. Podobnie, jak przy okazaniu, przepis nie obejmuje obecności adwokata osoby podejrzanej. W związku z tym zmianie powinien ulec art. 317 k.p.k. w takim samym kierunku, jak w odniesieniu do art. 316 k.p.k;

Zob. m.in.: J. Grajewski, Przebieg procesu karnego, Warszawa 2013, s. 59, R.A. Stefański, (w:) J. Bartoszewski, L. Gardocki, Z. Gostyński, S.M. Przyjemski, R.A. Stefański, S. Zabłocki, Kodeks postępowania karnego. Komentarz, Warszawa 2004, t. 2, s. 310; T. Grzegorczyk, Kodeks postępowania karnego. Komentarz, Warszawa 2008, s. 638 oraz literatura cytowana w opinii Komisji Kodyfikacyjnej Prawa Karnego dotyczącej implementacji dyrektywy 2013/48/UE. Opinie KKPK dostępne są na stronie: http://bip.ms.gov.pl/pl/dzialalnosc/komisje-kodyfikacyjne/ komisja-kodyfikacyjna-prawa-karnego/opinie-komisji-kodyfikacyjnej-prawa-karnego/ 
e) konfrontacji z udziałem osoby podejrzanej. Do konfrontacji zastosowanie mieć będzie art. 317 k.p.k., podobnie jak w przypadku odtworzenia przebiegu zdarzenia.

Przy wprowadzaniu zmian związanych z udziałem adwokata w czynnościach postępowania można by uwzględnić derogacje określone w art. 3 ust. 6 dyrektywy. Konieczne bowiem może okazać się przeprowadzenie danej czynności bez udziału adwokata, jeśli wymaga tego ochrona zdrowia lub życia człowieka bądź konieczność zabezpieczenia dowodów przed ich zniekształceniem lub utratą.

\section{Procedura ENA}

Obowiązujące przepisy prawa zapewniają już obecnie realizację prawa dostępu do adwokata w sytuacji, gdy Polska jest zarówno państwem wydania, jak i wykonania ENA. W sytuacji, gdy Polska jest państwem wydania, a więc toczy się w kraju postępowanie karne skierowane przeciwko osobie objętej ENA, do kontaktu z adwokatem i jego udziału w czynnościach zastosowanie mają przepisy ogólne k.p.k., tj. art. $244 \S 2$, art. $245 \S 1$, art. 73 k.p.k. - w zakresie pozbawienia wolności, jak też m.in. art. 79, art. 80 - w zakresie obowiązkowego udziału obrońcy w rozprawie. W przypadku, gdy Polska jest państwem wykonania ENA, zastosowanie mają przepisy ogólne dotyczące kontaktu $\mathrm{z}$ adwokatem lub obrońcą w przypadku pozbawienia wolności, jak również udziału obrońcy w przesłuchaniu przed sądem (art. 6071 $\S 1$ k.p.k.). Interwencji ustawodawcy może wymagać jednak przewidzenie możliwości wymiany informacji między organami państwa wykonania i wydania ENA oraz osobą objętą ENA w celu ułatwienia jej wyznaczenia adwokata w państwie wydania.

\section{Poufność kontaktów $z$ adwokatem}

Odrębnej uwagi wymaga kwestia poufnych kontaktów z adwokatem. KKPK w opinii na temat wdrożenia dyrektywy 2013/48/UE ${ }^{44}$ nie dostrzegła potrzeby zmiany przepisów ingerujących w swobodę kontaktów z adwokatem (art. 245 $\S 1$, art. 73 § 2 i 3 k.p.k.). KKPK wyraziła przekonanie, że dyrektywa dopuszcza ograniczenia zasady poufnych kontaktów $\mathrm{z}$ adwokatem $\mathrm{w}$ ramach postępowania karnego, wskazując m.in. na możliwość stosowania czasowych odstępstw w zakresie prawa do spotkań z adwokatem na osobności ${ }^{45}$.

44 Zob. opinię Komisji Kodyfikacyjnej Prawa Karnego w sprawie implementacji dyrektywy 2013/48/UE na stronie: http://bip.ms.gov.pl/pl/dzialalnosc/komisje-kodyfikacyjne/komisja-kodyfikacyjna-prawa-karnego/opinie-komisji -kodyfikacyjnej-prawa-karnego/

KKPK uznała, że zasada poufnych kontaktów z adwokatem nie ma charakteru absolutnego. Wyszła bowiem z założenia, że ograniczenia przewidziane w art. 3 ust. 6 dyrektywy, choć nie odnoszą się do art. 4 przewidującego tę zasadę, możliwe są wszelako w odniesieniu do spotkań z adwokatem na osobności (art. 3 ust. 3 lit. a). Wskazała również, że skoro dyrektywa nie wyklucza całkowitego, choć ograniczonego w czasie, wyłączenia możliwości kontaktowania się z obrońca, to trudno uznać, aby nie dopuszczała ograniczeń poufności tych kontaktów. W odniesieniu do poufnych kontaktów z adwokatem na gruncie ENA (art. 10 dyrektywy) KKPK uznała już jednak, iż do zasady tej nie stosuje się żadnych wyjątków. Takie rozumowanie trzeba jednak uznać za paradoksalne, bowiem celem dyrektywy nie było z pewnością ustanowienie bezwzględnej poufności kontaktów z adwo- 
Nie sposób jednak zgodzić się z KKPK, jakoby dyrektywa nie wprowadzała absolutnej zasady poufnych kontaktów z adwokatem. Art. 4 statuujący zasadę poufnych kontaktów z adwokatem nie przewiduje żadnych jej ograniczeń. Nie mają do tego przepisu zastosowania również czasowe odstępstwa określone w art. 3 ust. 6 dyrektywy. Odnoszą się one, co prawda, do spotkań z adwokatem na osobności (art. 3 ust. 3 lit. a), jednak ich celem jest wyłącznie opóźnienie w czasie dostępu do adwokata, nie zaś ingerencja w istotę poufności ${ }^{46}$. Wynika z tego, że w momencie, w którym prawo do spotkań $\mathrm{z}$ adwokatem będzie realizowane, powinno mieć ono charakter poufny. Zasada bezwzględnej poufności kontaktów z adwokatem potwierdzona jest również w motywie 33. preambuły, który wskazuje działania, jakie państwa powinny podejmować w celu jej ochrony (oraz wskazuje okoliczności niereglamentowane na drodze dyrektywy w szczególności podejrzenie o udział adwokata $\mathrm{w}$ działalności przestępczej wraz z podejrzanym lub oskarżonym).

W związku z tym zmiany we wskazanych wyżej przepisach są jednak konieczne. Zarówno przy zatrzymaniu, jak i tymczasowym aresztowaniu istnieje możliwość obecności, choć ograniczonej czasowo, funkcjonariusza policji, innej osoby zatrzymującej lub prokuratora przy rozmowie pozbawionego wolności z adwokatem (art. $245 \S 1$ k.p.k., art. $73 \S 2$ k.p.k.). Dodatkowo istnieje również możliwość kontroli korespondencji prowadzonej z obrońcą (art. $73 \S 3$ k.p.k.). Okazją do nowelizacji tych przepisów w kierunku zgodnym z dyrektywą mógł być senacki projekt ustawy o zmianie ustawy - Kodeks postępowania karnego oraz ustawy - Kodeks karny wykonawczy ${ }^{47}$, przygotowany w związku z wyrokami Trybunału Konstytucyjnego $^{48}$ stwierdzającymi ich niekonstytucyjność z powodu nieokreślenia przesłanek obecności osoby w trakcie rozmowy z adwokatem i kontroli korespondencji z nim ${ }^{49}$. Ustawodawca zdecydował się jednak na wprowadzenie zmian według wytycznych Trybunału $^{50}$, tj. zachowując możliwość odstępstw od poufności przy sprecyzowaniu,

katem jedynie w trybie ENA, a ograniczonej - w pozostałych przypadkach. Rozróżnienie to nie wynika z art. 4, ani też z art.10 odnoszącego się do ENA, w którym nie ma mowy o żadnych odrębnościach tego typu.

46 Zob. motywy 31. i 32. preambuły, które wyjaśniają, jakie działania państwa mogą podejmować stosując ograniczenia wskazane w art. 3 ust. 6 dyrektywy.

47 Projekt wykraczał poza wymogi wyroków TK, przewidywał bowiem wprowadzenie zasady poufności kontaktów $z$ adwokatem - uchylenie art. 73 § 2-4 k.p.k. oraz zmianę art. 245 § 1 k.p.k. poprzez wyeliminowanie możliwości zastrzeżenia obecności zatrzymującego podczas kontaktu osoby zatrzymanej z adwokatem (druk sejmowy 1349).

48 W wyroku z dnia 10 grudnia 2012 r. w sprawie K 25/11, TK uznał art. 73 § 3 za niezgodny z Konstytucją RP przez to, że nie wskazywał on przesłanek, których zaistnienie uprawniałoby prokuratora do zastrzeżenia kontroli korespondencji (Dz.U. 2012, 1426); w wyroku z dnia 11 grudnia 2012 r. w sprawie K 37/11, TK uznał art. 245 § 1 za niezgodny z Konstytucją RP przez to, że nie wskazywał przesłanki, której zaistnienie uprawnia zatrzymującego do obecności przy rozmowie zatrzymanego z adwokatem (Dz.U. 2012, 1447).

49 Trybunał nie dopatrzył się niekonstytucyjności ingerencji w zasadę poufnych kontaktów z adwokatem. Potwierdził swoje wcześniejsze stanowisko wyrażone w sprawie SK 39/02 dotyczącej zgodności art. 73 § 2 k.p.k. z art. 42 ust. 2 w zw. z art. 31 ust. 3 Konstytucji RP o dopuszczalnych granicach ustanawiania ograniczeń w korzystaniu z wolności i praw.

50 W sprawie 25/11 TK wskazał, że wystarczającą przesłanką usprawiedliwiającą kontrolę korespondencji z adwokatem będzie „szczególnie uzasadniony wypadek”, formuła stosowana już na gruncie art. 73 § 2 k.p.k. W sprawie K 37/11 TK nie wskazał konkretnego rozwiązania. 
wcześniej blankietowych, przesłanek derogacji. Kwestia rezygnacji z wyjątków od zasady poufności kontaktów z adwokatem została tym samym pozostawiona do uregulowania na okres implementacji dyrektywy.

Z uwagi na fakt, iż wspomniane przepisy k.p.k. mają zastosowanie również na gruncie ENA, nie zachodzi konieczność wprowadzania odrębnej regulacji w tym zakresie do Rozdziałów 65a i 65b k.p.k. regulujących tryb ENA.

\section{Zakończenie}

Dyrektywa 2013/48/UE może zyskać kluczowe znaczenie wśród instrumentarium unijnego dotyczącego praw procesowych w postępowaniu karnym. W dyskusjach podkreślano wręcz, że ma ona być dla praw procesowych tym, czym ENA był dla zasady wzajemnego uznawania. Przyjęcie tej dyrektywy ostatecznie potwierdza, że sfera gwarancyjna nie będzie miała jedynie charakteru akcesoryjnego wobec aktów unijnych o charakterze represyjnym, lecz że stała się immanentną częścią acquis w Przestrzeni Wolności, Bezpieczeństwa i Sprawiedliwości, której rozwój obecnie nie koncentruje się wyłącznie na interesie organów wymiaru sprawiedliwości, lecz z równym natężeniem - na bezpośredniej ochronie praw obywateli w UE.

Negocjacje dyrektywy pokazały szereg problemów wiążących się z rozumieniem poszczególnych aspektów prawa dostępu do adwokata w państwach członkowskich i odmienne podejścia, jakimi się dotąd kierowały. Częściowo zbliżenie standardów w tym zakresie wymuszało orzecznictwo ETPCz, nie rozstrzygnęło ono jednak wszystkich problemów. W kontekście prac nad dyrektywą istotnym wyzwaniem był zatem wspomniany na początku spór pomiędzy opportunity a guarantee approach (dostęp do adwokata, zależny od podjęcia inicjatywy przez samą osobę zainteresowaną contra „gwarancja" jego udostępnienia przez organy państwa w sytuacji, kiedy zainteresowany sam nie ustanowił obrońcy). Można uznać, że spór ten został rozstrzygnięty na rzecz tego pierwszego podejścia, bliższego procedurze polskiej. Świadczy o tym fakt, że w dyrektywie konsekwentnie wspomina się o prawie dostępu do adwokata, a obowiązki organów państwa ograniczać się mają do działań ułatwiających jego uzyskanie, nie zaś gwarantujących sam rezultat (w przypadku podejrzanych i oskarżonych pozbawionych wolności kładzie się ponadto nacisk na „skuteczność” działań). Niezależnie od tego, implementacja w Polsce będzie wiązała się z koniecznością wprowadzenia szeregu zmian w procedurze karnej.

Zaznaczyć warto, że Komisja przedstawiła już kolejne projekty aktów prawnych wdrażających mapę drogowa z 2009 r., w szczególności projekt dyrektywy w sprawie tymczasowej pomocy prawnej dla podejrzanych lub oskarżonych, którzy zostali pozbawieni wolności oraz w sprawie pomocy prawnej w ramach postępowania dotyczącego ENA ${ }^{51}$. Proponowane regulacje wiążą się ściśle z tematyką prawa 
dostępu do adwokata, tym niemniej trudno wstrzymać się z implementacją dyrektywy 2013/48/UE do czasu przyjęcia kolejnych pokrewnych instrumentów ${ }^{52}$, gdyż można się spodziewać, że negocjacje potrwają dłuższy czas, wykraczający poza wymagane terminy jej transpozycji.

Rzecz jasna, kluczowy efekt dla skuteczności zobowiązań wynikających z dyrektywy będą miały przepisy implementacyjne. $\mathrm{W}$ tym przypadku zdecydowano się na długi okres transpozycji, tj. 3 lata od jej wejścia w życie. Takie podejście było również wynikiem świadomości poważnych implikacji w porządkach wewnętrznych (niektórych) państw członkowskich tak na płaszczyźnie prawnej, jak i finansowej. Tym niemniej, zaakcentować trzeba alternatywne mechanizmy zapewnienia skuteczności tej dyrektywie, tj. możliwość jej bezpośredniego stosowania w prawie krajowym, w przypadku niepełnej implementacji lub jej braku. O ile Trybunał Sprawiedliwości wielokrotnie podkreślał, że dyrektywa samoistnie i niezależnie od wewnętrznej ustawy państwa członkowskiego wydanej w celu jej wykonania, nie może być podstawą ustalenia lub zaostrzenia odpowiedzialności karnej oskarżonych ${ }^{53}$, to sytuacja wygląda inaczej $\mathrm{w}$ razie nadania jednostce uprawnień $\mathrm{w}$ postępowaniu karnym ${ }^{54}$. W tym przypadku co najmniej część przepisów omawianej dyrektywy spełnia warunki bezpośredniego stosowania, w związku z czym jednostka, w razie wadliwej transpozycji krajowej, będzie mogła wywieść swoje uprawnienia bezpośrednio na podstawie dyrektywy ${ }^{55}$. Tego typu skutek nie był wcześniej znany w omawianym obszarze ze względu na fakt, iż art. 34 (2) (b) TUE w wersji przedlizbońskiej zastrzegał wyraźnie, że decyzja ramowa nie wywołuje skutku bezpośredniego. Nie ma również wątpliwości co do tego, że niniejsza dyrektywa wywoła skutek pośredni, tj. polegający na koniecznej wykładni przepisów prawa krajowego w świetle wynikających z niej zobowiązań. Tego typu efekt był już znany w obszarze współpracy sądowej ws. karnych na gruncie orzeczenia C-105/03 Pupino (w odniesieniu do decyzji ramowej), obecnie zaś znajdzie on potwierdzenie w bogatym orzecznictwie TSUE dotyczącym prounijnej wykładni prawa krajowego w świetle zobowiązań wnikających z dyrektyw ${ }^{56}$.

Końcowo należy zauważyć, że dyrektywa nie stanie się uniwersalnym narzędziem gwarantującym określone standardy procesowe w UE, gdyż 3 państwa członkowskie nie są nią związane ${ }^{57}$. I tak, Dania korzysta z wyłączenia (opt-out) we wszystkich instrumentach współpracy wymiarów sprawiedliwości UE ws. karnych przyjętych po wejściu w życie Traktatu z Lizbony ${ }^{58}$, z kolei Zjednoczone Królestwo

Wbrew sugestii KKPK wyrażonej w cytowanej wyżej opinii KKPK nt. transpozycji dyrektywy 2013/48/UE. Zob. np. sprawa C-148/78 lub sprawy połączone C-387/02, C-391/02 i C-403/02.

Zob. też: M. Wąsek-Wiaderek, Współpraca sądowa między TSUE a sądami krajowymi państw członkowskich, (w:) A. Grzelak, M. Królikowski, A. Sakowicz (red.), Europejskie Prawo Karne, Warszawa 2012, s. 285.

Zob. np. sprawa 41/74 Van Duyn oraz sprawa 148/78 Ratti.

Zob. np. sprawa 14/83 von Colson oraz C-106/89 Marleasing.

Zob. też T. Ostropolski, Judicial cooperation in criminal matters - 3 years with the Treaty of Lisbon, „Europejski Przegląd Sądowy" 2012, nr 11, s. 29.

58 Art. 1 Protokołu nr 22 w sprawie stanowiska Danii, dołączony do Traktatu z Lizbony. 
i Irlandia nie zdecydowały się przystąpić (opt-in) do dyrektywy ${ }^{59}$. Prowadzi to do niekorzystych następstw z punktu widzenia spójności Przestrzeni Wolności, Bezpieczeństwa i Sprawiedliwości w UE, mając na uwadze, że choć wszystkie państwa członkowksie są związane i stosują unijne instrumenty sądowe o charakterze represyjnym (np. DR ENA), to w tym przypadku nie są one kompensowane środkami gwarancyjnymi dla jednostek, zawartymi w omawianej dyrektywie. 


\section{RIGHT TO A LAWYER IN DIRECTIVE EU 2013/48 - EUROPEAN BACKGROUND AND IMPLICATIONS FOR THE POLISH LEGISLATOR}

The Treaty of Lisbon has introduced an explicit legal base concerning procedural safeguards in criminal proceedings. This has changed the focus of legislation in this field since previous measures concentrated mostly on prosecution and mutual recognition of judicial decisions. In that sense, Directive EU 2013/48 constitutes a milestone in implementation of the 2009 Council Roadmap on procedural rights of suspected and accused persons. The negotiations of the Directive were a fairly complex process given the divergent approaches to right of access to a lawyer in member states and the dynamic evolution of the jurisprudence of ECHR in this field. For the most part, Polish legislation already complies with the Directive. However, amendments may be necessary, particularly concerning early phase of questioning by the police, certain evidence gathering acts, as well as confidentiality of communications with a lawyer. In case of non-implementation, the national courts will also be able to rely directly on the provisions of the Directive, which is a new challenge in the area of criminal law.

Keywords: lawyer, procedural rights, European arrest warrant, implementation 